\title{
VREDNOSTI KOJE UTIČU NA STABILNOST PRAVNOG PORETKA*
}

\author{
Marko Trajković** \\ Univerzitet u Nišu, Pravni fakultet
}

Vrednosti koje utiču na stabilnost pravnog poretka zapravo su ontološka osnova pravnog poretka koji se još može označiti i kao državno-pravni poredak. Ako se pravni poredak u svom normativnom delu može označiti kao sistem prava jasno je da taj sistem mora da počiva na nečem što je snažnije od sankcije. Država predstavlja prema normativističkoj pravnoj teoriji personifikaciju prava, te samim tim pitanje ontološko-aksiološke osnove prava postaje izraženije. Jasno je da se stabilnost jednog poretka ne može izgraditi nikakvim centralizmom niti sankcijama, već ,jednostavnom" verom u vrednosti koje taj poredak u sebi nosi. Vreme u kome se pravni poredak može označiti kao stabilan društveni fenomen mora da bude ispunjeno aksiološkim sadržajima.

Ključne reči: pravo, vrednosti, pravni poredak, pravni sistem, stabilnost

\section{Uvod}

Dravni poredak se sastoji od svog normativnog elementa, odnosno od pravnog sistema i od svog faktičkog elementa, odnosno od ponašanja ljudi po pravnim normama. Dakle, tako određen pravni poredak putem pravnih normi pravnog sistema uređuje društvene odnose unutar određene zajednice i čini in justicijabilnim.

Kako se pravni poredak jednim svojim delom sastoji od pravnih normi putem kojih izražavamo zapovesti, postaje jasno da je sadržinski deo tih zapovesti veoma važno ispuniti vrednosnim sadržajem, koji će potom obezbediti stabilnost pravnog poretka putem ponašanja ljudi prema tom sadržaju. Pravni poredak je istovremeno i veoma dinamična pojava koja se mora prilagođavati društvenim uslovima, te postaje jasno da će to biti još jedan od izazova za stabilnost pravnog poretka.

Sadržinski posmatrano tu ,jaku“ stabilnost mogu da mu podare samo vrednosti kao i vrednosno procenjivanje stvarnosti. Ako pravni poredak želimo da shvatimo kao autoritet postaje jasno da taj autoritet vrši svoju ontološku dužnost samo preko svog aksiološkog sadržaja, odnosno on se neće iscrpeti u „prostoj“ naredbi. Ovo govori da će čovek biti „okrenut" ka autoritetu samo ako veruje u njegova dela. Naravno dešava se da čovek u

\footnotetext{
* Ovaj članak je rezultat istraživačkog rada u okviru projekta br. 179046 „Zaštita ljudskih i manjinskih prava u evropskom pravnom prostoru“ Pravnog fakulteta u Nišu koji finansira Ministarstvo za nauku i tehnološki razvoj Republike Srbije.

** Dr Marko Trajković je redovni profesor.
} 
autoritet veruje ako mu to što „tretira“ kao autoritet „daje dovoljno razloga da vjeruje ili da djela u skladu s tim bez obzira što on sam inače ne može uvidjeti dobar razlog za to vjerovanje ili djelanje ili što ne može vrednovati razloge koje uviđa ili što uviđa neki suprotan razlog ili razloge, ili bi sam drugačije (tj. u odsustvu onoga što on tretira kao autoritativno) preferirao da tako ne vjeruje ili ne djela“. ${ }^{1}$

\section{Vrednosti kao autoritet u pravnom poretku}

Autoritet koji počiva na sili nije autoritet već sila i on neće obezbediti stabilnost kao društveni fenomen niti će biti dugotrajan, već će se ispoljiti u golom nasilju. Analizirajući Finisovo shvatanje (John Finnis) dolazimo do stanovišta da je čovek u dodiru sa pravom na terenu čiste heteronomije kada mora da ispunjava zahtev izražen u dispoziciji pravne norme, jer čovek kao „animal sociale, živi u formi prava“. ${ }^{2}$ Taj zahtev je uvek imperativne prirode i u sebi neće sadržati ništa osim zahteva za izvršenje, što znači da se čovek u tu formu uklapa „Voljno ili s otporom“3 ali se uklapa. Postaje veoma važno kakav je sadržaj tog zahteva koji se mora ispuniti, posebno ako se kod prava, za razliku od morala koji je autonoman, može primetiti da od nas zahteva izvršenje i onda kada mi ne možemo naći u sebi valjan razlog za ispunjenje onoga što pravna norma od nas zahteva. Iz tog razloga, a posebno što pravo i neće pitati, zbog svoje heteronomne suštine, za motive našeg izvršenja naredbe važno je da vrednosti budu osnov dispozicije. Jasno je da „Autoritet (i stoga odgovornost upravljanja) u zajednici treba da vrše oni koji mogu stvarno efektivno da riješe koordinacione probleme te zajednice". Iz ovog razloga nameće se stav da su vrednosti jedini autoritet koji u skladu sa razumom mogu da reše probleme zajednice, zbog jednostavne vere u njih od strane pripadnika zajednice, ali i zbog same definicije aksiologije koja se terminološki određuje kao „aksios - vredan i logos - nauka“. 5

Ovo postaje veoma važno jer „Činjenica da će autoritativni iskaz određene osobe ili tjela ili konfiguracije osoba, uglavnom biti poštovan ima normativne posljedice za praktičnu razumnost“. ${ }^{6}$ A takva činjenica tera na zaključak da je autoritet koji od nas nešto zahteva ispunjen u svom sadržaju vrednostima, čime postaje jasno da smo na putu ostvarenja stabilnosti pravnog poretka, koji se u svom faktičkom delu i sastoji od našeg ponašanja.

Saglasnost koju dajemo autoritetu mora da počiva na veri koju ispoljava „praktično razuman subjekt“ u „zajedničko dobro“ koje taj autoritet sobom nosi. ${ }^{7}$ Naravno da se ovde ne može govoriti o neutemeljenoj preferenciji ili vezanosti sopstvenim vrednostima, već se može govoriti o vezanosti onim vrednostima koje su date u stvarnosti. Opasnost leži u voluntarizmu koji može uneti lične preferencije u pravni poredak koji će se potom

\footnotetext{
${ }^{1}$ Dž. Finis, Prirodno pravo, CID, Podgorica, 2005, 245.

2 J. Binder, Prilog učenju o pojmu prava, Dosije, Beograd, 2008, 5.

${ }^{3}$ Ibid.

${ }^{4}$ Dž. Finis, Prirodno pravo, 256.

${ }^{5}$ M. Životić, Aksilogija, Naprejed, Zagreb, 1986, 23.

${ }^{6}$ Dž. Finis, Prirodno pravo, 256.

${ }^{7}$ Dž. Finis, Prirodno pravo, 261.
} 
udaljiti od sopstvene stabilnosti, odnosno može dovesti do „arbitrernih preferencija među licima“8 ${ }^{*}$ koje će u svojoj osnovi povrediti vrednost jednakosti do i pred zakonom.

Opasnost od ličnih preferencija čoveka koji raspolaže disrekcionim ovlašćenjima koja bazira isključivo na svom vrednosnom sudu Hart (Herbert Hart) je ocenio kao nešto što može da bude razlog uništenja pravnog poretka. Ovo će se desiti putem pojmova morala koji vrše upliv na pravo, a koje on naziva fantomskim. Prema takvom stavu „postojanje i sadržaj prava“ je takva „društvena činjenica, čija je veza sa moralnim ili bilo kojim drugim vrednostima kontigentna i nesigurna“. ${ }^{9}$ Ovakva postavka prava je "deo demitologizacije prava, usađivanja racionalnih kritičkih stavova u njega" ${ }^{10}$ kojom se uostalom bavio i Hans Kelzen (Hans Kelsen) želeći da pravo očisti od svih ostalih primesa. lako deluje „obećavajuće" godine prošlog veka dokazuju suprotno sa svojim zakonima koji su bili ispunjeni zločinačkom sadržinom iako su bili formalno-pravno zakoni odnosno letimni deo pravnog poretka. Iz tog razloga postaje jasno da pravnici veoma često „svakako znaju šta je po pravu, ali neće znati šta je pravo ako za neko vreme ne napuste svoje empirijske principe i izvor svojih sudova ne potraže u čistome umu“. ${ }^{11}$

Sasvim opravdano izražavamo žaljenje što je pravna teorija „posrnula“ pred pravnim pozitivizmom koji je „Svojim uverenjem „zakon je zakon“ potom „razoružao nemački pravnički stalež prema zakonima sa samovoljnom i zločinačkom sadržinom", a do toga je i došlo jer pozitivizam „uopšte nije u stanju da vlastitom snagom obrazloži važenje zakona“. ${ }^{12}$ Ovde je učinjena čista zamena teza te je društveno-pravna vrednost pravde zamenjena pravnom sigurnošću u nadi da će ona sama po sebi doneti željenu stabilnost pravnog poretka.

Zapravo se radilo o tome da su ljudi težeći ka nedostižnoj „apsolutnoj sigurnosti“ prihvatili „konkretnu sigurnost“"13 koja im je u tom trenutku bez vrednosnog razmišljanja bila dostižna. Tada je autoritet pravde zamenjen autoritetom sigurnosti, ali pravna sigurnost nije ,jedina i nije presudna vrednost koju pravo ima da ostvari“. ${ }^{14}$ Te druge vrednosti obezbeđuju da pravo nije i neće postati samo vođina zapovest, jer „Tamo gde pravo ne bi bilo ništa drugo do vođina zapovest, ostalo bi neobjašnjeno obvezivanje i samog vođe putem prava...". 15

Tada autoritet ima samo sankcije za svoj oslonac koje su se pokazale kao nedovoljno snažne da čak i njega samog održe. Iz tog razloga Herman Heler (Hermann Heller) postavlja pitanje: „Pravna država ili diktatura?“. ${ }^{16}$ Autoritet može da se osloni samo na silu ali „Time je ideal pravde izgubio za zakonodavca svoje važenje i pao u formalne maksime uprave koja je, bez obzira na pravednu ili nepravednu sadržinu zakona, zahtevala njegovu proračunljivu primenu na pojedinačan slučaj“ te je postala važna samo „računska priroda“ i „si-

\footnotetext{
${ }^{8}$ Ibid, 116.

${ }^{9}$ Dž. Raz, Etika u jevnom domenu, CID, Podgorica, 2005, 229.

${ }^{10} \mathrm{lbid}$.

${ }^{11}$ J. J. Bahofen, Prirodno pravo i istorijsko pravo, Dosije, Beograd, 2008, 7.

${ }^{12}$ G. Radbruh, Pravni i drugi aforizmi, Dosije studio, Beograd, 2007, 18.

${ }^{13}$ G. Vukadinović, D. M. Mitrović, M. Trajković, Uvod u pravo, Dosije studio, Beograd, 2012, 291.

${ }^{14} \mathrm{G}$. Radbruh, Pravni i drugi aforizmi, 13.

${ }^{15}$ Ibid, 7.

${ }^{16}$ Radi se zapravo o istoimenom delu Hermana Helra, H. Heler, Pravna država ili diktaura?, Dosije studio, Beograd, 2011.
} 
gurnost zakona, a ne više njegova ispravnost“. ${ }^{17}$ Što dalje znači da „Ima naroda koji egzistuju bez tla, bez države, bez crkve, samo u „zakonu“; njima se normativističko mišljenje čini jedino razumnim pravnim mišljenjem, a svaka druga vrsta mišljenja nepojmljivom, mističnom, fantastičnom ili smešnom“" ${ }^{18} \mathrm{Na}$ taj način nastaje potpuno neutemeljena vera u savršenost normativističke postavke pravnog poretka koji egzistira bez greške.

Ali da bi se ostvario „san“ čistog normativiste „koji se svagda vraća normi kao osnovi svoga pravnog mišljenja“" ${ }^{19}$ neophodno je da ta norma bude utemeljena na vrednostima.

\section{Nestabilnost pravnog poretka uzrokovana sukobom vrednosti}

Problem stabilnosti pravnog poretka istovremeno je problem moralnog života „s kojim se neprekidno bore filozofija i sam život. Večna borba filozofije vodi se oko problema moralnoga i dobroga“. ${ }^{20}$ Dakle, sama borba oko stabilnosti pravnog poretka predstavlja "samo simbolični izraz za večnu borbu samoga života za svoje moralne sadržaje“.21

Nestabilnost pravnog poretka veoma često je uzrokovana sukobom pravnih vrednosti. Taj sukob može biti toliko veliki da potpuno naruši čvrstinu temelja pravnog poretka, jer se vera u vrednosti suprotstavlja namerama pravnog pozitivizma koji je „najpre značio nešto polemičko: odbacivanje svakog „vanzakonskog“, svakog prava koje nije stvoreno ljudskim propisom, bilo da se javlja kao božansko, prirodno ili umno pravo". 22 To je značilo da se kurs pravne nauke menjao a „Pravno mišljenje postaje mišljenje legalnosti“ te se u stvaranju takvog kursa „prošlo kroz tri stadijuma: najpre se držalo volje zakonodavca; potom se, da ne bi zapalo u subjektivna i psihološka istraživanja, govorilo o volji zakona; najzad, merodavnim je proglašen samo još sam zakon, norma koja je dovoljna samoj sebi“ ${ }^{23}$

Svako povezivanje sa aksilogijom tretirano je kao „prirodnopravna „korupcija“24 koja nanosi štetu pravnoj sigurnosti pravnog poretka te utiče na nestabilnost ideje legaliteta pravnog poretka koja se zasniva na "normativnoj snazi faktičkoga“ a pokreće je „normativna motivaciona snaga prava“. ${ }^{25}$

Međutim, takav pravnik koji „gradi svoj stan u kodeksu pozitivnih zakona“ pretvara se u „zatvorenika“ koji se neće usuditi „da gleda preko njegovih visokih zidova“26 te će na taj način svesno ili nesvesno podrivati i same zidine pravnog poretka. Dakle, pravnici su odbili da se uzdignu od "sluge zakona do njihovog gospodara“ te su još odbili da poreknu „zakonsko radi pravnog“ i odbiju „formalno važeće pravo u korist onoga koje filozofski važi“ . ${ }^{27}$

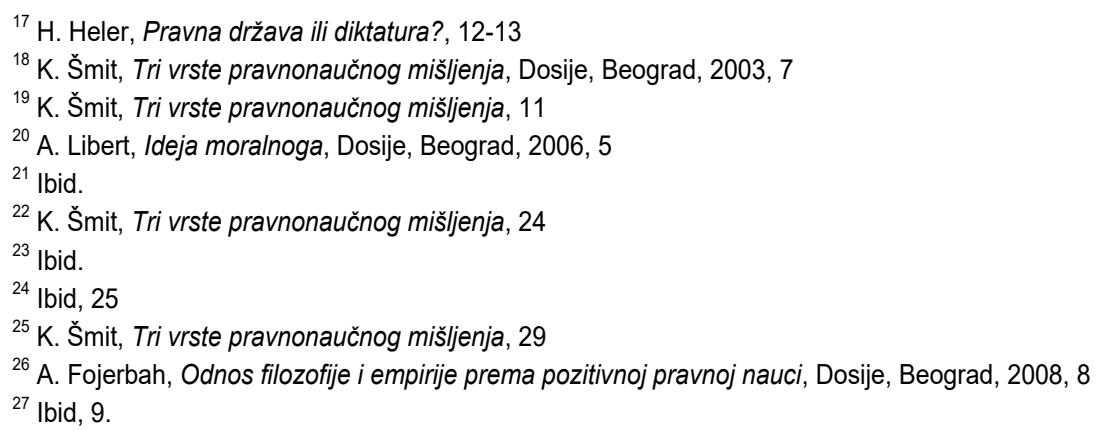


Aksiologija je jasna jer tvrdi da „Nezavisno od svakog pozitivnog zakonodavstva, u ljudskoj prirodi leži kao krajnji izvor svih prava i svih obaveza zakon uma..." ${ }^{28}$ koji korača ispred pozitivnog prava i gradi čvršći i stabilniji pravni poredak od onog koji je sagrađen isključivo na normativnim pretpostavkama.

Kada pravni poredak bude usvojio sledeću krilaticu on može da računa na svoju stabilnost, dakle: „Tek kad su prava postala izvesna, tek onda o državo! možeš da osiguraš ta prava“. ${ }^{29}$ A kada ta država ćuti, odnosno „ako zakonodavac ćuti““30 ko govori? Izgleda da tada govori aksiologija koja mora da „zauzme njegovo mesto i osvetli svojom buktinjom ono što je njegovom oku ostalo skriveno“. 31

Pravo međutim pripada a sa njim i stabilnost pravnog poretka jednom drugačijem carstvu, oni pripadaju "carstvu duha ili slobode, carstvu smisaonih tvorevina, stvarnosti uslovljene vrednostima, oblikovane prema idejama“32 i tako ostvaruju svoju dugotrajnost. U tom carstvu mi „sasvim instinktivno zahtevamo da čovek bude dobar ${ }^{\text {r33 }}$ te u tome tražimo osnovu za stabilnost pravnog poretka. Zapravo, mi stabilnost pravnog poretka ne možemo tražiti u nečem mističnom niti samo u kolektivitetima, već najpre tražimo u individui, odnosno čoveku bez imena i lica. Dakle, tražimo ontološki u čoveku koji želi da bude dobar, jer „Filozofski problemi takođe nastaju iz neposrednog odnosa prema samom životu, snabdeveni su tom unutrašnjom neotklonjivošću koju sve što je živo nosi u sebi, a ono što filozofija čini sa svoje strane, nije ništa drugo nego što tu životnu neposrednost problema podiže do visine pojma, što duh istorije i duh života pribavljaju sebi u svojoj filozofiji pojmovni odraz, logički izraz svoje sopstvene istine i svoje sopstvene večnosti“. ${ }^{34}$

Ovako stvar postaje jednostavna, jer je jasno da je početak stabilnosti u čoveku samom, i kada se pitamo ko je taj ko mora da ostvari stabilnost, odgovor je veoma brz: „Mi uvek treba nešto da učinimo“. ${ }^{35}$ A ovo je jasno jer „Pravni poredak može živeti samo ako su određeni članovi pravne zajednice ispunjeni ne samo svojim posebnim interesom nego i pravnom svešću koja leži u osnovi tog poretka“. ${ }^{36}$

U razvijanju te svesti a u cilju održanja stabilnosti pravnog poretka jasno je da postoji samo moralna obaveza pokoravanja vrednostima ali ne i moralna obaveza pokoravanja zakonima bez obzira na njihovu sadržinu. Dakle, ta sadržina je ono što nas upravlja a ne „prosta“ sankcija istaknuta u pravnoj normi, jer pravo „sačinjavaju validni moralni principi koji su najbliži (tj. najsličniji) iskazima koji reprezentuju namere zakonodavca i sudova“. ${ }^{37}$

Ako je opšte prihvaćeno „da države i međunarodno pravo treba da priznaju takvo jedno pravo samo ako imaju jake moralne razloge ${ }^{\text {“38 }}$ onda je potpuno jasno da građani mo-

\footnotetext{
${ }^{28}$ Ibid, 11.

${ }^{29} \mathrm{lbid}$.

${ }^{30}$ lbid, 37.

${ }^{31}$ lbid.

32 J. Binder, Prilog učenju o pojmu prava, 27.

${ }^{33}$ A. Libert, Ideja moralnoga, 5.

${ }^{34}$ A. Libert, Ideja moralnoga, 11.

${ }^{35}$ Ibid, 45.

${ }^{36}$ G. Radbruh, Pravni i drugi aforizmi, 41.

${ }^{37}$ Dž. Raz, Etika u javnom domenu, 320.

${ }^{38}$ Ibid, 141
} 
raju da priznaju jedno pravo i pravni poredak, u ovom slučaju unutrašnje pravo, samo ako imaju „jake moralne razloge“. Ovo bi se moglo označiti kao „moralno pravo na samoopredeljenje “39 kojim se možemo rukovoditi kao razlogom poslušnosti a u cilju održanja stabilnosti pravnog poretka.

Ljudska praksa te onda i pravna „odvija se kao proces sukoba heteronomnih i autonomnih vrednosti“40 a tome dodajemo i osnovni sukob pravnih vrednosti koji uz prethodni može veoma snažno da „potrese“ stabilnost pravnog poretka. Ono što nijedan pravni poredak ne može da naruši, ontološko-aksiloški posmatrano, je jednakost i taj atribut pravnog poretka istakao je Ruso (Jean Jacques Rousseau) kada je napisao: „Kad kažem da je predmet zakona uvek opšti, pod tim podrazumevam da zakon posmatra podanike kao jednu celinu, a radnje uzima apstraktno; nikad ne gleda na čoveka kao pojedinca niti na radnju kao pojedinačnu, konkretnu radnju. Tako, na primer, zakon može da utvrdi da će biti privilegija, ali ne može da ih daje poimenice nikome; zakon može da stvori više klasa građana, čak i da odredi i osobine koje daju pravo na te klase, ali ne može da poimenice ovoga ili onoga uvrsti u njih...". ${ }^{41}$ Ruso je to tačno napisao, ali nije bio svedok nacističkih zakona sa zločinačkom sadržinom, koji nisu samo zapisali nejednakost, već je i sproveli. A do ovoga je došlo jer je u trenutku zenita pravnog pozitivizma pravna sigurnost postala ideja vodilja prava sa svim strahotama koje je potom donela.

Najpre je rečeno da je pravo „ono što je po svome smislu određeno da služi ideji prava“ a tu ideju smo našli u „pravdi““2 a potom smo je napustili nekako „razočarani“ što nismo mogli da je dostignemo. To napuštanje se desilo u ime pravne sigurnosti, jer smo samo poželi da imamo pravo, a ne i da sačekamo pravdu. Ovo naše razočarenje u zakasnelu pravdu pretočili smo u stav „ako se ne može utvrditi šta je pravedno, mora se propisati šta će biti po pravu (rechtens) i to od strane organa koji je u stanju i da sprovede ono što je propisao". ${ }^{43}$ Tako smo zakoračili u praznu formulu pravnog pozitivizma gde je puka pozitivnost prava bila dovoljna da se pravo nazove ispravnim, jer je po principu pravnosnažnosti bilo „Važnije da se spor između pravnih gledišta okonča, nego da se on okonča pravedno...". 44

Odavde se krenulo a završilo sa neutemeljenim „razmetanjem“ da je važnije „postojanje pravnog poretka nego njegova pravednost..."45 a završilo tragično, kao i svaka simpatija za đavola koji želi da „važi“ bez obzira što je „loš“. Na isti način i pravna sigurnost „zahteva pozitivnost, ali pozitivno pravo hoće da važi bez obzira na njegovu pravednost..." ${ }^{46}$ a tako na kraju „protivpravne činjenice mogu da unište objektivno pravo“47 dok će pravnosnažnost da dopusti „važenje i sadržinski neispravnoj odluci...." 48

\footnotetext{
${ }^{39}$ Ibid, 143.

${ }^{40}$ M. Životić, Aksiologija, 49.

${ }^{41}$ Ž. Ž. Ruso, Društveni ugovor, Prosveta, Beograd, 1949, 33.

${ }^{42}$ G. Radbruh, Filozofija prava, Nolit, Beograd, 1980, 94.

${ }^{43}$ lbid, 95.

${ }^{44}$ lbid.

${ }^{45}$ Ibid.

${ }^{46} \mathrm{G}$. Radbruh, Filozofija prava, 97

${ }^{47}$ lbid, 98

${ }^{48}$ lbid.
} 
Istorija kao svedok ovakvih pravnih postupaka beleži slučaj „Antigone“ ali se tu nije zaustavila i pokrenula je spiralu samouništenja pravnih poredaka koji su se bazirali za ideji „pravo je pravo“ a „naredba je naredba“ te je tako u listu „Süddeutsche Juristen-Zeitung" objavljena i protumačena jedna odluka prvostepenog suda u Vizbadenu, po kojoj su „zakoni koji su proglašavali da svojina Jevreja pripada državi, u protivrečnosti sa prirodnim pravom, i da su još u vreme njihovog donošenja bili ništavni“ ${ }^{49}$

Spisak zakona koji su sačinjavali tadašnji pravni poredak Nemačke uzrokovao je potpuno „legalnu“ a „suludo idiotsku hajku na Jevreje ${ }^{\text {‘50 }}$ što je bio praktičan vid razaranja ideje pravnog poretka, koji je uostalom bio sve samo ne pravni poredak. Taj pravni poredak uostalom nisu mogli da čini oni pravnici koji ,još uvek nisu u punoj meri usvojili nacionalsocijalistički duh“. ${ }^{51}$

Naravno ovaj je „manir" zahvatio sve delove društva te se tako može govoriti i o „Svinjarijama koje su počinili štreberski profesori i docenti na univerzitetima, istiskujući svoje Jevrejske kolege..."52 a sve pod velom pravnog poretka koji je navukao neke „zlobive naočare "53 te kroz njih posmatrao stvarnost lišenu vrednosti.

$\mathrm{Na}$ pitanje zašto se iznova i iznova dešavaju ovakve stvari Niče (Freidch Neitzsche) odgovara: „To sam uradio, kaže moje pamćenje. Nije moguće da sam to učinio, kaže moj ponos. Na kraju pamćenje popušta“. ${ }^{4}$ Ovakav stav kao i prihvatanje da društvene nauke mogu da budu vrednosno neutralne doveo je do čiste deskripcije „očiglednih postupaka, kakvi se mogu zapaziti u koncentracionim logorima...". 55

Pravni poredak koji odbija da prihvati vrednosne sudove i sve žrtvuje zarad konačnog a brzog rešenja onemogućava sebe da stvari „nazove“ pravim imenom te da načini razliku između „autentičnog i lažnog, između višeg i nižeg; između prave religije i lažne religije, između pravog vođe i šarlatana, između znanja i učenosti ili sofizma, između vrline i poroka, između moralne osetljivosti i moralne tuposti, između umetnosti i kiča, između vitalnosti i degeneracije itd. "56

Mogući sukob vrednosti koji docnije može uticati na stabilnost pravnog poretka nije se zaustavio na odnosu pravda - pravna sigurnost. Pravda je kao društveno-pravna vrednost došla potom u sukob sa svrsishodnošću, koja za razliku od pravde koja uopštava čak i princip jednakosti, mora "koliko god da je to mogućno da individuališe“. 57

Potom možemo posmatrati vrednost koja najpre kod svih posmatrača prva ukazuje na stabilnost ili nestabilnost pravnog poretka, na mir. Mir koji dolazi u vezu sa redom i sigurnošću može da menja svoju suštinu jer „red sam po sebi ima vrednost, i to jednu veliku vrednost...". ${ }^{58}$ Gde u aksiološkom smislu nailazimo na problem sa pojmom kao što je

\footnotetext{
${ }^{49}$ Ibid, 281.

${ }^{50}$ H. Broh, Pisma o Nemčkoj: 1945-1949, Svetovi, Novi Sad, 1994, 10.

51 lbid, 14

52 Ibid, 19.

53 lbid, 75.

${ }^{54}$ lbid, 132, f. 4

${ }^{55}$ L. Štraus, Prirodno pravo i istorija, Plato, Beograd, 1997, 45.

${ }^{56}$ Ibid, 53.

${ }^{57}$ G. Radbdruh, Filozofija prava, 97.

${ }^{58}$ Đ. Tasić, „Pravda i red kao principi prava“, u Izbor rasparava $i$ članaka iz teorije prava, 211-212, Navedno prema: G. Vukadinović, D. M. Mitrović, M. Trajković, Uvod u pravo, 293.
} 
to red? To je tamo gde se on meša sa pojmovima poput mira, i sa konstatacijom da pored izvesnosti on zahteva primenu prinude od strane organizovanog državnog aparata koji to čini putem svojih normi koje potom postaju „veoma važni činioci kojima se obezbeđuje red“. ${ }^{59} \mathrm{Na}$ ovaj način uvodimo i pojam „primjene organiziranog nasilja nad ljudima“ 60 što sa svoje strane kompromituje ideju.

Ovo kompromitovanje ideje dolazi iz odnosa „žive napetosti“61 između vrednosti koja potom utiče na stabilnost koja mora da izražava vrednosnu suštinu pravnog poretka. ${ }^{62}$ Stabilnost se istovremeno izražava u odsustvu voluntarizma i ličnih preferencija jer „nalaženje „ispravnog prava“ u pojedinačnom slučaju ne treba više da bude prepušteno samovolji i ličnom taktu, nego treba da bude, od strane filozofski školovanog sudije, preduzeto jednostavnim prenošenjem najvišeg pravnofilozofskog kriterijuma vrednosti...".6

Zašto je važno uneti „red“ čak i među vrednostima da bi se ostvarila stabilnost poretka? Veoma je važno preći put u održanju stabilnosti od stanja koje je stvoreno pravom koje je prosta „tehnika čoveka-gospodara za kroćenje stada; gospodareva samovolja..." ${ }^{\text {"64 }}$ do stanja koje govori o veri u pravni poredak.

Iz ove očigledne napetosti proizlazi kao jasan zaključak da aksiološki problemi koji utiču na stabilnost nisu doneti spolja već proističu iz same suštine stvarnosti koja je izražena u napetosti koju podržava formalizam u pravu koji sa svoje strane liči na „drvenu glavu bez mozga“. ${ }^{5}$

Ali nije stvar stala ovde, ovaj sukob se pruža i preko pitanja pojedinih vrednosti koje same u sebi nose sadržaj koji ako nije valjano shvaćen u stvarnosti unosi nestabilnost u pravni poredak, kakav je slučaj sa slobodom koja na neki način predstavlja jedinu vrednost koju želimo da ograničimo za razliku od drugih čije ostvarenje želimo apsolutno. Dakle, iako je sloboda takvog ontološkog karaktera da je „od svih stvari najpreča“66 ona je istovremeno i ona koju želimo da ograničimo iz straha da će nas razoriti umesto da postane „pozitivna moć vlastitog određenja osobe“. ${ }^{67}$ Osoba koja je odgovorna za svoju i tuđu slobodu time je postala ono lice koje u svojoj vlastitoj slobodi ne može naći razloge za „moralnu niskost“. ${ }^{68}$ Tako se na ovaj način potvrđuje da se sloboda nalazi u „lancu ontoloških uvjeta“. ${ }^{69}$ Ovi ontološki uslovi dovode do pitanja odnosa slobode i zakona kao osnove za održanje stabilnosti pravnog poretka, jer zapravo pravna stvarnost nudi odnos „sloboda pod zakonom“ - „sloboda iznad zakona“. ${ }^{70}$ Valjano ostvarenje ravnoteže između ova dva zahteva uneće preko potrebnu

\footnotetext{
${ }^{59}$ G. Vukadinović, D. M. Mitrović, M. S. Trajković, Uvod u pravo, 293.

${ }^{60}$ N. Visković, Pojam prava, Logos, Split, 1981, 139.

${ }^{61}$ G. Radbruh, Filozofija prava, 98.

${ }^{62}$ E. Lask, Filozofija prava i kraći spisi, Dosije, Beograd, 2005, 31.

${ }^{63}$ Ibid, 31-32.

${ }^{64}$ H. Heler, Pravna država ili diktatura?, 16.

${ }^{65} \mathrm{~J}$. J. Bahofen, Prirodno pravo i istorijsko pravo, 7.

${ }^{66}$ Zapravo, izvorno stoji: LIBERTATIS OMNIBUS REBUS FAVORABILIOR EST, „Sloboda je od svih stvari najpreča“, DIG, 50, 17; 122. Navedeno prema: V. Kamps, Javne vrline, Filip Višnjić, Beograd, 2007, poleđina knjige.

${ }^{67}$ N. Hartmann, Etika, Naklada LJEVAK, Zagreb, 2003, 348.

${ }^{68}$ Ibid, 350.

${ }^{69}$ lbid, 746-747.

${ }^{70}$ N. Hartmann, Etika, 749.
} 
stabilnost, jer je ovo povezano sa „slobodom ili autonomijom pojedinca kao i sa njegovom sposobnošću da obeća nešto sebi, i naročito, drugima sve do tačke odgovornosti za svoja dela". ${ }^{71}$ Tako se pravni poredak, kao sa jedne strane sistem pravnih normi, može u svom zahtevu za sopstvenom stabilnošću povezati sa idejom prava kao mogućnosti „povezivanja opće uzajamne prisile sa svačijom slobodom“. ${ }^{72}$ Kada pravni poredak bude „živeo“ ideju u kojoj čovek sam ograničava svoju slobodu bez prisile on će ostvariti punu stabilnost. Dakle, ovde bi govorili o vlasti koju pojedinac ima nad samim sobom a ne o granicama „vlasti koju društvo može legitimno da ima nad pojedincem“. ${ }^{73}$ Tada se lični autoritet menja za autoritet društva ili države u ostvarenju sopstvenog ograničenja slobode, te se pristaje na poredak prisile umesto na poredak vrednosti. A u tom poretku vrednosti jasno je da je i sloboda volje nešto što se može „najbolje objasniti upućivanjem na fizičku prirodu“ jer je sloboda „isto tako temeljno određenje volje kao što je težina temeljno određenje tjela“." ${ }^{4}$ Pravni poredak u svom faktičkom delu predstavlja jedinstvo prava i slobode jer „Svaki stupanj razvoja ideje slobode ima svoje vlastito pravo, jer je on opstojanje slobode u jednom njenom vlastitom određenju“. ${ }^{75}$ A ograničenje koje čovek sam sebi postavlja i iz koga proističe prava stabilnost nalazi se u postavci personalnosti koja sa svoje strane ispoljava zahtev „budi osoba (Person) i poštuj druge kao osobe“. ${ }^{76}$ Tada nam nije potrebna „patrimonijalna sudijska vlast“ jer „pojedinac je sebe zaštitio“77 svojom odgovornošću koja je na nivou moralnog saznanja stvarnosti jer „moralitet, prikazuje stoga u cjelini realnu stranu pojma slobode...."78

Pravni poredak koji pledira na stabilnost neguje u sebi slobodu postupanja koja je ,jedinstvo teorijskog i praktičnog duha“", ${ }^{79}$ duha koji se bavi filozofijom slobode, a ne onom filozofijom koja se može odrediti kao „filozofija moći“" ${ }^{80}$ a koja je odraz niza „improvizovanih, proizvoljnih dekreta“"81 koji su opet proizvod „slepe strasti" ${ }^{\circ 2}$ koja narušava stabilnost najpre u čoveku samom kao individui, a potom i u poretku kao odrazu kolektiviteta.

\section{Zaključak}

Veoma je nerealno očekivati da će se stabilnost kolektiviteta, kakav je u drugom svom elementu pravni poredak, ostvariti ako se prethodno nije ostvarila stabilnost u čoveku jer je i individua u svojoj punini „sadržaj svih pojava“, 83 odnosno sadržaj i opštih i

\footnotetext{
${ }^{71} \mathrm{~V}$. Kamps, Javne vrline, 51

${ }^{72}$ I. Kant, Metafizika ćudoređa, Matica hrvatska, Zagreb, 1999, 28.

${ }^{73}$ Dž. S. Mil, O slobodi, Plato, Beograd, 1998, 35.

${ }^{74}$ G. W. F. Hegel, Osnovne crte filozofije prava, Veselin Masleša - Svjetlost, Sarajevo, 1989, 35.

${ }^{75}$ Ibid, 71.

${ }^{76}$ lbid, 84.

${ }^{77}$ Ibid, 145.

${ }^{78}$ Ibid, 190.

${ }^{79}$ G. W. F. Hegel, Enciklopedija filozofijskih znanosti, Veselin Masleša - Svjetlost, Sarajevo, 1987, 409.

${ }^{80}$ L. Štraus, Prirodno pravo i istorija, 146.

${ }^{81} \mathrm{lbid}, 175$.

${ }^{82}$ lbid, 209.

${ }^{83}$ A. Šopenhauer, Svet kao predstava i volja, Matica srpska, Novi Sad, 1981, 257
} 
pojedinačnih pravnih akata jednog pravnog poretka. Taj pravni poredak može „sanjati“ svoju stabilnost jedino ako je vezan za vrednosti koje čine njegovu obavezujuću snagu, a te vrednosti dolaze u svom ostvarenju u stvarnosti od slobodne volje čoveka koja je volja „po sebi i izvan pojave slobodna“. ${ }^{84}$ Dakle tačno je „La liberté est un mystère“. ${ }^{85}$ I ne samo da je tajna, već je to tajna koja otvara vrata stabilnosti poretka u nama i izvan nas.

A poredak izvan nas kakav je, zbog heteronomnosti prava, pravni poredak može izgraditi svoju stabilnost ako stekne „svest o pravednosti“" ${ }^{\text {“ }}$ i time spreči „zločin iz ravnodušnosti“ . 87 Ovakvi zločini uticali su na nestabilnost pravnog poretka kao vrednosti, ali ne i na nestabilnost pravnog poretka kao forme, zbog čega i izražavamo zabrinutost nad pozitivističkim tendencijama koje se danas „rasplamsavaju“. Suprotno od toga vrednosni sudovi zahtevaju apsolutno procenjivanje stvarnosti nasuprot ravnodušnom prepuštanju činjenicama. Tako je jasan stav da se apsolutna pokornost formalno-pravnim zahtevima ne može odrediti kao tačka od koje će se uzdići pravni poredak. Jasno je na primer „Ne postoji pravna obaveza denuncije..." ${ }^{88}$ koja je raširena u totalitarnim pravnim sistemima, a u cilju njihovog održanja, te je potpuno prihvatljivo „Ko je u tim godinama nekoga denuncirao morao je računati s tim - a to je i činio - da optuženog ne predaje zakonitom sudskom postupku sa pravnim garantijama za istraživanje istine i za pravednu presudu, nego ga predaje samovolji“. ${ }^{89}$ Kako se u pravu, koje je i nauka i ideja ali i praksa, nalazi potreba za preciznošću tako se mora prihvatiti stav da je „Pravo uvek samo instrument koji pravnik svestan svoje odgovornosti upotrebljava da bi došao do pravno održive presude“. ${ }^{90}$ Pravnik mora da prihvati da je za važenje pravu potrebno više od forme, jer "Zakonodavstvo nacionalsocijalističke partijske države, na osnovu kojeg su izrečene smrtne presude kao ove navedene, nema nikakvo pravno važenje“. ${ }^{91}$ Pravno logiciranje u ispravljanju zločina koji su nepravedni zakoni učinili ide i u pravcu da se donose zakoni koji čak i svojim nazivom nište učinke ovakvih zakona, a takav je jedan bio „Zakon o ispravljanju nacional-socijalističkog neprava u krivičnom pravosuđu“. ${ }^{2} \mathrm{Na}$ ovaj način se želi i formalno-pravno da ostvari povratak ka stabilnosti poretka koji je narušen zgradom nepravednih zakona koji su potom stvorili nepravedan pravni sistem. Ovim postaje jasno da je pravni poredak stabilan u onoj meri u kojoj je vrednost jer on nije „svrha dovoljna samoj sebi“ ${ }^{33}$ već je njegova svrha čovek kao individua, i ljudi kao kolektivitet. Ovo je jedini način da se izbegne „fetišiziranje vlasti“" ${ }^{494} u$ ime stabilnosti. Što je zapravo i osnova pretpostavke šta je to norma jer ona „pretpostavlja vrijednost kojoj obezbjeđuje egzistenciju i zahtjeva njeno oživotvorenje“. ${ }^{95}$

\footnotetext{
${ }^{84}$ Ibid, 269

85 „Sloboda je tajna“ u: A. Šopenhauer, Svet kao predstava i volja, 355

${ }^{86}$ H. Broh, Pisma o Nemačkoj: 1945-1949, 41

${ }^{87}$ Ibid, 52

${ }^{88}$ G. Radbruh, Filozofija prava, 282

${ }^{89} \mathrm{Ibid}$.

${ }^{90}$ lbid, 285

${ }^{91} \mathrm{lbid}$.

92 Ibid, 290

${ }^{93}$ A. Tanović, Vrednost i vrjednovanje, Svjetlost, Sarajevo, 1978, 25

${ }^{94}$ Ibid, 24

${ }^{95}$ Ibid, 37.
} 


\section{Literatura}

[1] Bahofen, J. J, Prirodno pravo i istorijsko pravo, Dosije, Beograd, 2008.

[2] J. Binder, J, Prilog učenju o pojmu prava, Dosije, Beograd, 2008.

[3] Broh, H, Pisma o Nemačkoj: 1945-1949, Svetovi, Novi Sad, 1994.

[4] Visković, N, Pojam prava, Logos, Split, 1981.

[5] Vukadinović, G, Mitrović, D, M, Trajković, M, Uvod u pravo, Dosije studio, Beograd, 2012.

[6] Životić, M, Aksilogija, Naprejed, Zagreb, 1986.

[7] Kamps, V, Javne vrline, Filip Fišnjić, Beograd, 2007.

[8] Lask, L, Filozofija prava i kraći spisi, Dosije, Beograd, 2005.

[9] Libert, A, Ideja moralnoga, Dosije, Beograd, 2006.

[10] Mil, Dž. S, O slobodi, Plato, Beograd, 1998.

[11] Radbruh, G, Filozofija prava, Nolit, Beograd, 1980.

[12] Radbruh, G, Pravni i drugi aforizmi, Dosije studio, Beograd, 2007.

[13] Raz, Dž, Etika u jevnom domenu, CID, Podgorica, 2005.

[14] Ruso, Ž. Ž, Društveni ugovor, Prosveta, Beograd, 1949.

[15] Tanović, A, Vrednost i vrjednovanje, Svjetlost, Sarajevo, 1978.

[16] Finis, Dž, Prirodno pravo, CID, Podgorica, 2005.

[17] Fojerbah, A, Odnos filozofije i empirije prema pozitivnoj pravnoj nauci, Dosije, Beograd, 2008.

[18] Hartmann, N, Etika, Naklada LJEVAK, Zagreb, 2003.

[19] Hegel, G. W. F, Enciklopedija filozofijskih znanosti, Veselin Masleša - Svjetlost, Sarajevo, 1987.

[20] Hegel, G. W. F, Osnovne crte filozofije prava, Veselin Masleša - Svjetlost, Sarajevo, 1989.

[21] Heler, X, Pravna država ili diktaura?, Dosije studio, Beograd, 2011.

[22] Šmit, K, Tri vrste pravnonaučnog mišljenja, Dosije, Beograd, 2003.

[23] Šopenhauer, A, Svet kao predstava i volja, Matica srpska, Novi Sad, 1981.

[24] Štraus, L, Prirodno pravo i istorija, Plato, Beograd, 1997. 